AGRICULTURE AND BIOLOGY JOURNAL OF NORTH AMERICA

ISSN Print: 2151-7517, ISSN Online: 2151-7525, doi:10.5251/abjna.2011.2.8.1187.1193

(C) 2011, ScienceHu $\beta$, http://www.scihub.org/ABJNA

\title{
Antimicrobial activities of some Nigerian spices on some pathogens
}

\author{
Olusimbo O. Aboaba, Abimbola Rashidat Ezeh and Chinonye Leticia Anabuike \\ Department of Microbiology, Faculty of Science, University of Lagos, Nigeria
}

\begin{abstract}
The aqueous and ethanol extracts of four spices ( Monodora myristica, Piper guineense, Xylopia aethiopica, Tetrapleura tetraptera ) were prepared and the antibacterial properties assessed using the agar diffusion method. The test organisms were Enterohaemorrhagic E.coli, Shigella, Salmonella, Klebsiella, Pseudomonas, Klebsiella pnemonium, Staphylococcus aureus, Staphylococcus aureus (ATCC 25923), Bacillus sp. and Enterococcus faecalis. The susceptibility of the test bacteria strains to various antibiotics was performed. The aqueous extracts had antimicrobial activities on all test organisms used (MIC values of $30-60 \mathrm{mg} / \mathrm{ml}$ and a range of inhibition, $10-25 \mathrm{~mm})$. The ethanol extracts were less sensitive $(3.3-26 \mathrm{mg} / \mathrm{ml}$ on $E$. feacalis). The phytochemical screening of the potent extracts revealed the presence of terpenoids, flavonoid and glycosides. The test organisms showed susceptibility to majority of the antibiotics used ranging from an average of $10 \mathrm{~mm}-37 \mathrm{~mm}$. The aqueous extracts can be used as an alternative therapy to the use of antibiotics as the zones of inhibition exhibited by the test strains to both were comparable.
\end{abstract}

Key words: Antimicrobial, plant extract, phytochemical, Inhibitory and agar diffusion

\section{INTRODUCTION}

Spices which include plant materials of medicinal importance have been used for the treatment of human ailments as far back as prehistoric times (Cowan, 1999). Spices are used as condiments and ingredients in foods. In Nigeria, some are used for the preparation of certain type of soups which are delicacies and also recommended for fast relief of ailments such as malaria fever (Sofowora, 1993). The use of medicinal plants in traditional medicine has been recognised and widely practised. According to the World Health Organization, $80 \%$ of the world's population rely on traditional medicines to meet their health regiments (Maffi, 1999). Many commercially proven drugs used in modern medicine were initially used in crude form in traditional or folk healing practices or for other purposes that suggested potentially useful biological activity. Medicinal plants generally contain a number of compounds which may be potential natural antibacterial for the treatment of common bacterial infections (Ratnasooriya et al., 2005). It is estimated that today, plant materials are present in or have provided models for $50 \%$ of western drugs (Robbers, 1996). Plant derived medicines are relatively safer than synthetic alternatives, offering profound therapeutic benefits and more affordable treatment (Kareem et al., 2010, Raskin et al., 2002). Therefore there is urgent and continuous need to discover new antimicrobial compounds with diverse chemical structures and novel mechanisms of action for new and re-emerging infectious diseases (Rojas et al., 2003).

\section{MATERIALS AND METHODS}

Sample Collection: The spices Xylopia aethiopica, Monodora myristica, Tetrapleura tetraptera and Piper guineense were purchased and identification confirmed by a plant taxonomist at the Department of Botany, University of Lagos, Akoka.

Bacterial strains: The test organisms were obtained from the Department of Microbiology and Parasitology, Lagos University Teaching Hospital, (LUTH). Cultures of these test organisms were maintained on Nutrient agar slants at $4^{\circ} \mathrm{C}$. The test organisms were:-

- Gram-negative: Enterohaemorrhagic E.coli (EHEC), Shigella, Salmonella, Klebsiella, Pseudomonas and Klebsiella pneumonia.

- Gram-positive: Staphylococcus aureus, Staphylococcus aureus (ATCC 25923), Bacillus $s p$ and Enterococcus faecalis.

Extraction of Spices: Approximately $250 \mathrm{gm}$ of each of the pulverised spices was weighed, suspended in $100 \mathrm{ml}$ of distilled water and $70 \% \mathrm{v} / \mathrm{v}$ ethanol and left to stand in the refrigerator for four (4) days. The extracts were filtered and dried in the oven at $60^{\circ} \mathrm{C}$. Each of the dried extract was reconstituted and stored in the refrigerator at $4^{\circ} \mathrm{C}$ prior to use. 
Preparation of bacterial culture: The stock culture of each of the bacteria used was subcultured at $37^{\circ} \mathrm{C}$ for 24 hours. The culture was emulsified in $3 \mathrm{ml}$ sterile saline and adjusted using 0.5 McFarland's standard.

Assay for antimicrobial activity: Antimicrobial activity was determined using the agar diffusion method (Rojas et al., 2003). Wells made into previously seeded Mueller Hinton agar plates containing $10^{8} \mathrm{cfu} / \mathrm{ml}(0.5 \mathrm{McF}$ arland's standard) of each of the test organism were filled with $0.2 \mathrm{ml}$ of each extract. Ethanol $(70 \% \mathrm{v} / \mathrm{v})$ and sterile distilled water were used as controls. The plates were incubated at $37^{\circ} \mathrm{C}$ for $24 \mathrm{hrs}$. All tests were performed in duplicates and antimicrobial activity expressed as the mean diameter of the clear zone $(\mathrm{mm})$ produced by the plant extracts. Varying concentrations of the extracts were prepared and the above procedure repeated. Minimum inhibition concentrations were determined for each extract. The bacteriostatic and bacteriocidal effects were determined as the plates were further incubated for another $48 \mathrm{hrs}$. The ability to maintain clear zone after $72 \mathrm{hrs}$ was considered as bactericidal and the presence of tiny colonies on the zone of inhibition was taken as bacteriostatic.

\section{Determination of Minimum inhibitory} concentration (MIC): The extracts that exhibited considerable activity were diluted double fold (2:2) with nutrient broth in a series of six test tubes. An aliquot of $1 \mathrm{ml}$ of the bacterial suspension $\left(1 \times 10^{8}\right)$ was inoculated into each tube. The control tubes were inoculated with same quantity of sterile distilled water and $75 \%$ ethanol. All tubes were incubated at $37^{\circ} \mathrm{C}$ for $24 \mathrm{~h}$. The lowest concentration that did not permit any visible growth when compared with the control was considered as the minimum inhibitory concentration. The contents of all tubes that showed no visible growth were cultured on MacConkey agar plates and incubated at $37^{\circ} \mathrm{C}$ for $24 \mathrm{hrs}$. The minimum bacteriocidal concentration was considered as the lowest concentration that could produce a single bacterial colony.

Antibiotic susceptibility pattern of test strains:

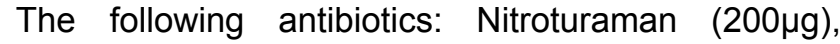
Gentamycin $(10 \mu \mathrm{g})$, Naldixic $(30 \mu \mathrm{g})$, Ofloxacin $(200 \mu \mathrm{g})$, Augmentin $(30 \mu \mathrm{g})$, Tetracycline $(10 \mu \mathrm{g})$, Amoxicillin $(200 \mu \mathrm{g})$, Cotrimoxazole $(25 \mu \mathrm{g})$, Chloramphenicol $(10 \mu \mathrm{g})$, Cloxacillin $(5 \mu \mathrm{g})$, and Erythromycin $(5 \mu \mathrm{g})$, were purchased from ABTEK laboratories, Liverpool, UK. The susceptibility of the test bacteria strains to various antibiotics was performed following National Committee for Clinical Laboratory Standard Recommendation (NCCLS, 2006a). McFarland's standard (0.5) was used to standardize bacteria suspension to $10^{8} \mathrm{CFU} / \mathrm{ml}$. Sterile swabs were dipped into the standardized bacterial suspensions and then streaked in three directions over the surface of the agar plate and allowed to dry for $5 \mathrm{mins}$ before the antibiotics were applied. The zones of inhibition were recorded after incubation at $37^{\circ} \mathrm{C}$ for $24 \mathrm{~h}$.

Phytochemical analysis of plant extracts: Qualitative phytochemical analysis (Harbone, 1998) of some of the extracts that had maximum antibacterial activity was determined for the presence of alkaloids, flavonoids, glycosides, tannins, terpenoids and saponins.

\section{RESULTS}

Assay for antimicrobial activity: The aqueous extracts showed antibacterial activities on the test organisms used. Zone of inhibition ranged from 12$25 \mathrm{~mm}$ with Piper guineense and $10-18 \mathrm{~mm}$ with Xylopia aethiopica. The ethanol extracts had minimal effect on the test organisms. (Tables 1 and 2).

Table 1: Zones of inhibition of aqueous extracts of the spices in $\mathbf{m m}$

\begin{tabular}{|l|l|l|l|l|l|}
\hline Test organism & Piper guineense & $\begin{array}{l}\text { Mondora } \\
\text { myristica }\end{array}$ & $\begin{array}{l}\text { Tetrapleura } \\
\text { tetraptera. }\end{array}$ & $\begin{array}{l}\text { Xylopia } \\
\text { aethiopica }\end{array}$ & Control \\
\hline Shigella & 20 & 0 & 8 & 0 & 0 \\
\hline S.aureus & 25 & 0 & 10 & 18 & 0 \\
\hline ATCC 25923 & 20 & 0 & 15 & 18 & 0 \\
\hline K. pneumonia & 15 & 0 & 10 & 0 & 0 \\
\hline Klebsiella & 20 & 0 & 15 & 11 & 0 \\
\hline E. feacalis & 20 & 10 & 10 & 15 & 0 \\
\hline Bacillus & 20 & 10 & 11 & 0 & 0 \\
\hline Salmonella & 20 & 0 & 12 & 0 & 0 \\
\hline Pseudomonas & 23 & 0 & 10 & 10 & 0 \\
\hline EHEC & 12 & 0 & 10 & 0 & 0 \\
\hline
\end{tabular}


Table 2: Zones of inhibition of ethanol extracts of the spices in $\mathbf{~ m m}$

\begin{tabular}{|l|l|l|l|l|l|}
\hline Test organism & Piper guineense & $\begin{array}{l}\text { Mondora } \\
\text { myristica }\end{array}$ & $\begin{array}{l}\text { Tetrapleura } \\
\text { tetraptera }\end{array}$ & $\begin{array}{l}\text { Xylopia } \\
\text { aethiopica }\end{array}$ & Control \\
\hline Shigella & 10 & 0 & 0 & 10 & 0 \\
\hline S.aureus & 15 & 0 & 10 & 10 & 0 \\
\hline ATCC 25923 & 15 & 0 & 10 & 0 & 15 \\
\hline K. pneumonia & 0 & 0 & 0 & 0 & 0 \\
\hline Klebsiella & 13 & 10 & 0 & 13 & 0 \\
\hline E. feacalis & 0 & 0 & 13 & 0 & 0 \\
\hline Bacillus & 10 & 0 & 0 & 10 & 0 \\
\hline Salmonella & 0 & 0 & 0 & 6 & 0 \\
\hline Pseudomonas & 6 & 0 & 0 & 0 & 0 \\
\hline EHEC & 0 & 0 & & 0 \\
\hline
\end{tabular}

Effect of concentration on antimicrobial activity showed that the trend was similar for all extracts as higher concentrations produced wider zone of inhibition. (Figures 1-7).

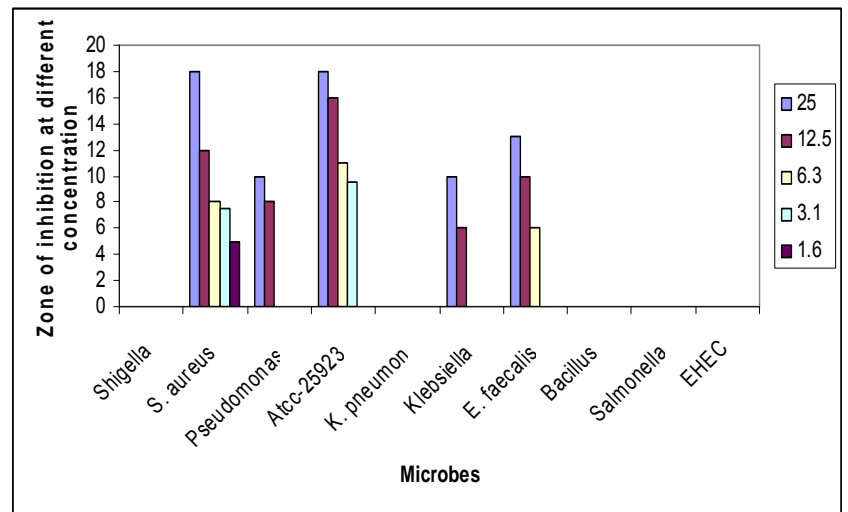

Fig 1: Graph showing zone of inhibition $(\mathrm{mm})$ of aqueous extract of $X$. aethiopica at different concentration $(\mathrm{mg} / \mathrm{ml})$ on the test organisms.

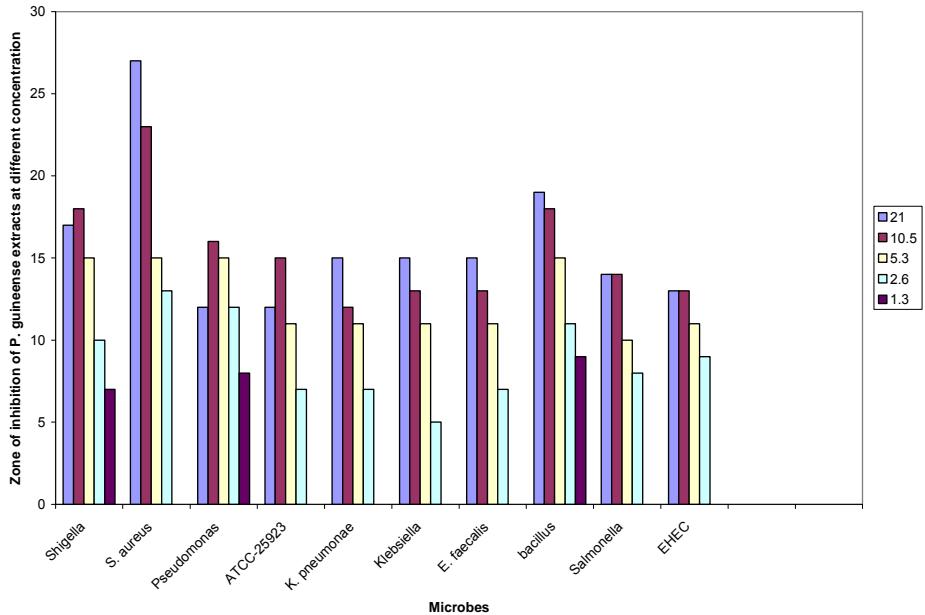

Fig 2: Graph showing zone of inhibition ( $\mathrm{mm})$ of aqueous extract of $P$. guineense at different concentration $(\mathrm{mg} / \mathrm{ml})$ on the test organisms. 


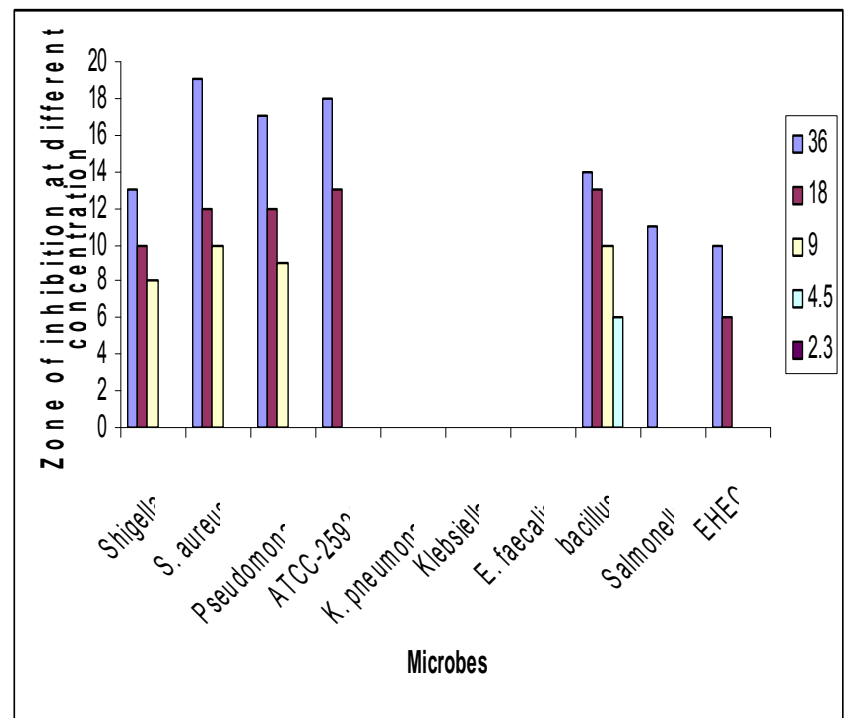

Fig 3: Graph showing zone of inhibition $(\mathrm{mm})$ of aqueous extract of $T$. tetraptera at different concentration in $\mathrm{mg} / \mathrm{ml}$ on the test organisms.

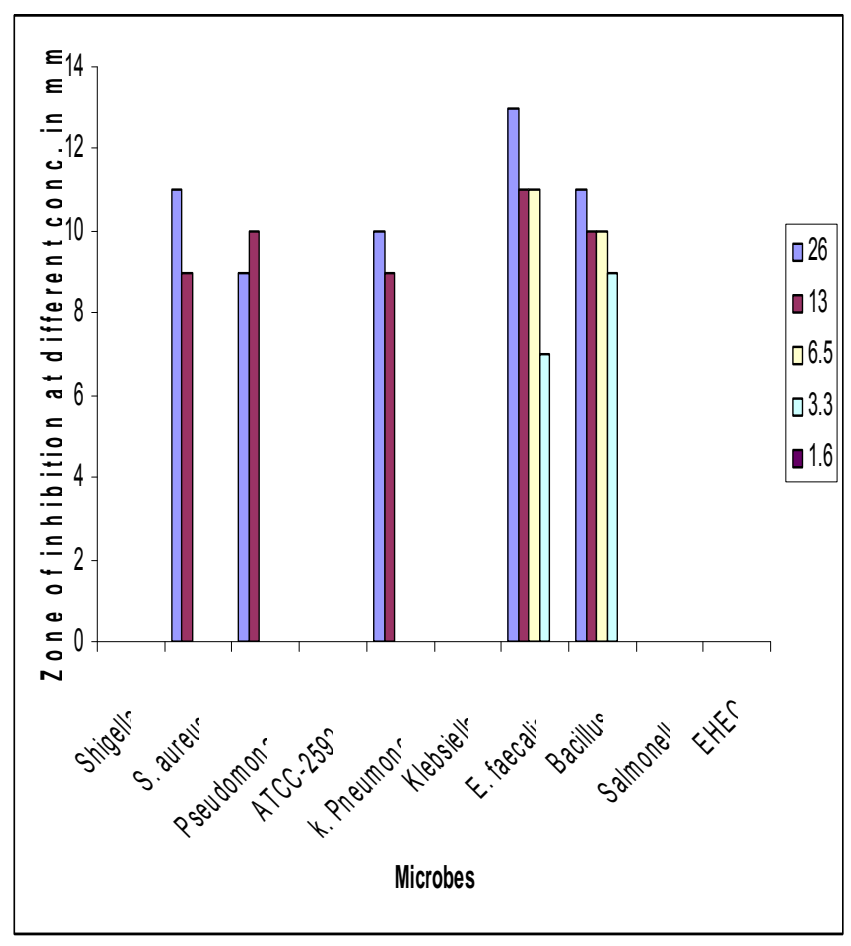

Fig 4: Graph showing zone of inhibition $(\mathrm{mm})$ of ethanol extract of $X$. aethiopica at different concentration in $\mathrm{mg} / \mathrm{ml}$ on the test organisms.

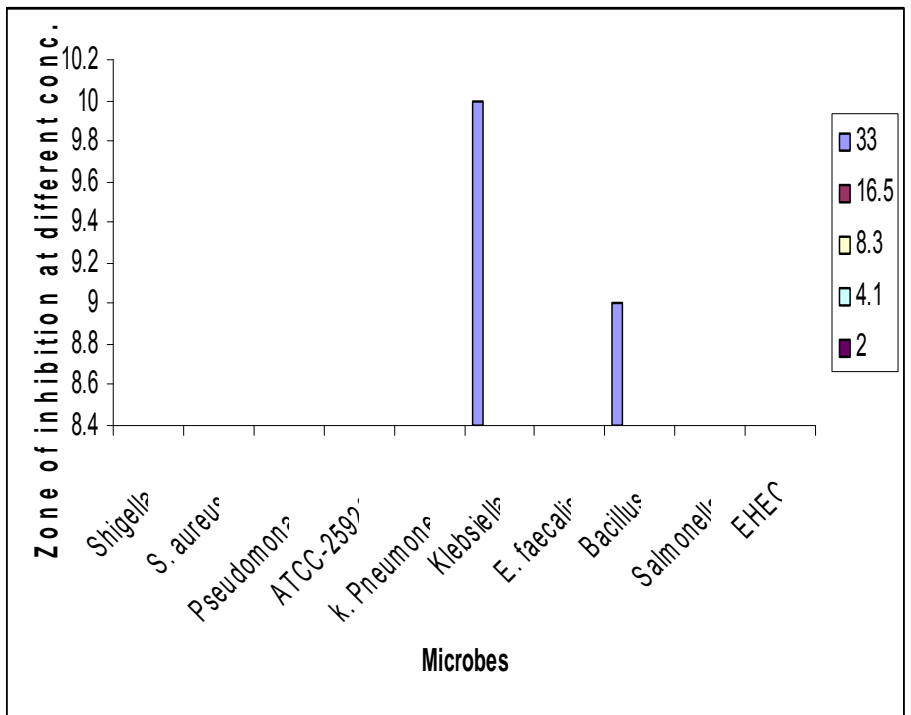

Fig 5: Graph showing zone of inhibition $(\mathrm{mm})$ of ethanol extract of $M$. myristica at different concentration in $\mathrm{mg} / \mathrm{ml}$ on the test organisms.

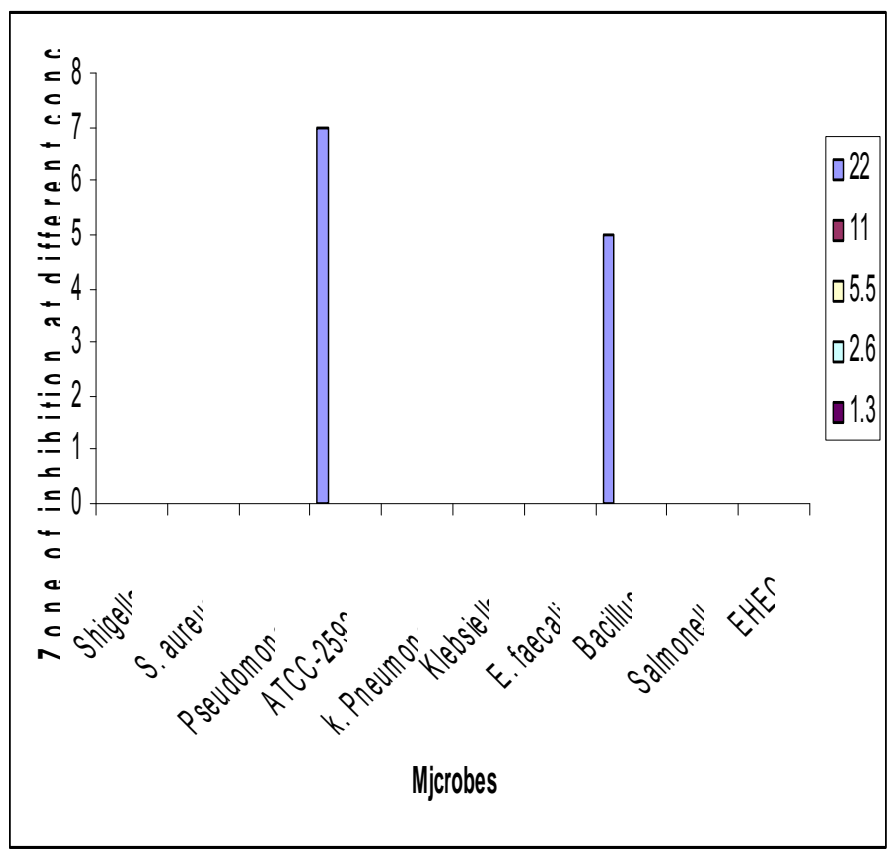

Fig 6: Graph showing zone of inhibition $(\mathrm{mm})$ of ethanol extract of $P$. guineense at different concentration in $\mathrm{mg} / \mathrm{ml}$ on the test organisms. 


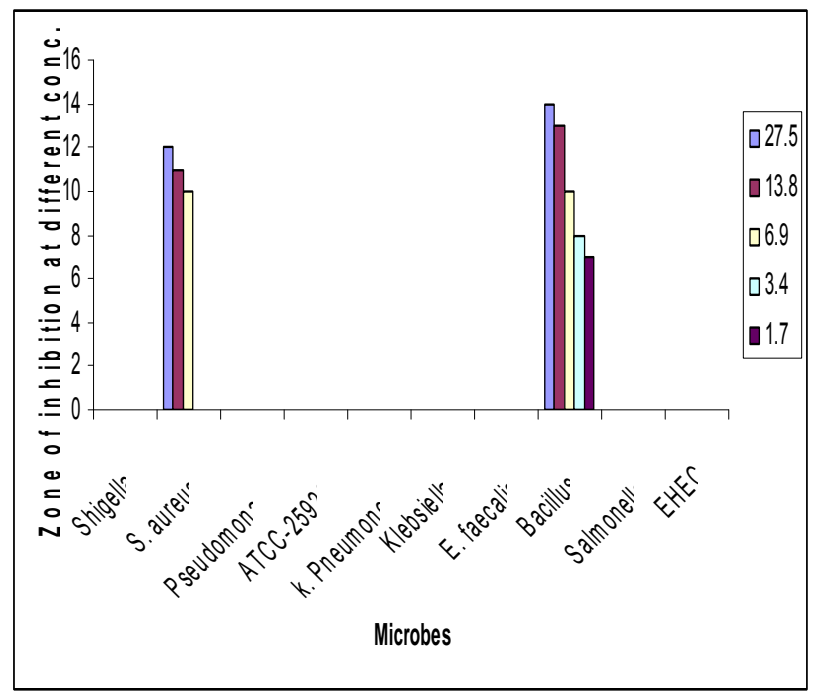

Fig 7: Graph showing zone of inhibition $(\mathrm{mm})$ of ethanol extract of $T$. tetraptera at different concentration in $\mathrm{mg} / \mathrm{ml}$ on the test organisms.

Determination of MIC: The aqueous extracts had antimicrobial activities on all test organisms used with MIC values of $30-60 \mathrm{mg} / \mathrm{ml}$. Some however were bacteriocidal while others were bacteriostatic (Table 3 ). The ethanol extracts were less sensitive (3.3$26 \mathrm{mg} / \mathrm{ml}$ on $E$. feacalis).

\section{Antibiotic susceptibility pattern of test strains}

The bacterial isolates showed susceptibility to majority of the antibiotics used ranging from an average of $10 \mathrm{~mm}-35 \mathrm{~mm}$. They all showed resistance to at least one of the antibiotics. None showed total resistance to all the antibiotics (Tables 4 and 5)

Table 3: Result of bacteriostatic and bactericidal effect after 72 hours of incubation

\begin{tabular}{|c|c|c|c|c|c|c|c|c|}
\hline \multirow[t]{2}{*}{ Organism } & \multicolumn{2}{|c|}{ Piper guineense } & \multicolumn{2}{|c|}{ Monodora myristica } & \multicolumn{2}{|c|}{ Xylopia aethopica } & \multicolumn{2}{|c|}{ Terapleura tetraptera } \\
\hline & $\mathrm{aq}$ & $a / c$ & $\mathrm{Aq}$ & $a / c$ & $\mathrm{Aq}$ & $a / c$ & $\mathrm{aq}$ & $a / c$ \\
\hline Shigella & $\mathrm{BI}$ & $\mathrm{Bc}$ & $\mathrm{Bc}$ & - & - & - & $\mathrm{Bc}$ & - \\
\hline S.aureus & $\mathrm{Bl}$ & - & $\mathrm{Bc}$ & $\mathrm{BI}$ & $\mathrm{Bl}$ & $\mathrm{Bc}$ & $\mathrm{Bc}$ & $\mathrm{Bc}$ \\
\hline Pseudomoniae & $\mathrm{BI}$ & - & $\mathrm{Bc}$ & - & $\mathrm{Bc}$ & $\mathrm{Bc}$ & $\mathrm{BI}$ & - \\
\hline EHEC & $\mathrm{BI}$ & - & $\mathrm{Bc}$ & - & - & $\mathrm{Bc}$ & $\mathrm{Bc}$ & - \\
\hline ATCC 25923 & $\mathrm{Bl}$ & $\mathrm{Bc}$ & $\mathrm{Bc}$ & - & $\mathrm{Bl}$ & $\mathrm{Bc}$ & $\mathrm{Bl}$ & $\mathrm{Bc}$ \\
\hline K. pneumonia & $\mathrm{BI}$ & - & $\mathrm{Bc}$ & - & $\mathrm{Bc}$ & $\mathrm{BI}$ & $\mathrm{BI}$ & - \\
\hline Klebsiella & $\mathrm{Bl}$ & - & $\mathrm{Bc}$ & $\mathrm{Bc}$ & - & $\mathrm{BI}$ & - & - \\
\hline E. feacalis & $\mathrm{Bc}$ & - & $\mathrm{Bc}$ & - & - & $\mathrm{Bc}$ & - & - \\
\hline Bacillus & $\mathrm{BI}$ & $\mathrm{Bc}$ & $\mathrm{Bc}$ & $\mathrm{BI}$ & $\mathrm{BI}$ & $\mathrm{BI}$ & - & $\mathrm{BI}$ \\
\hline Salmonella & $\mathrm{BI}$ & - & $\mathrm{Bc}$ & - & $\mathrm{BI}$ & $\mathrm{Bc}$ & - & - \\
\hline
\end{tabular}

\section{Bl----Bactericidal}

Bc---Bacteriostatic

Table 4: Antibiotics Susceptibility pattern of Gram Positive strains in $\mathrm{mm}$

\begin{tabular}{|l|l|l|l|l|l|l|l|l|}
\hline Bacteria & \multicolumn{9}{|c|}{ Antibiotics } \\
\hline & Cxc & Gen & Cot & Chl & Aug & Amx & Ery & Tet \\
\hline $\begin{array}{l}\text { Enterococcus } \\
\text { faecalis }\end{array}$ & 0 & 14.5 & 19 & 14 & 28 & 15.5 & 0 & 0 \\
\hline $\begin{array}{l}\text { Staphylococcus } \\
\text { aureus }\end{array}$ & 12 & 10 & 0 & 26 & 25 & 16 & 16 & 0 \\
\hline Bacillus sp. & 0 & 25 & 0 & 24 & 14 & 11.5 & 11 & 23 \\
\hline Staphylococcus & 22 & 30 & 33 & 22 & 35 & 34 & 0 & 24 \\
\hline
\end{tabular}


Table 5 Antibiotics Susceptibility pattern of Gram Negative strains in $\mathbf{m m}$

\begin{tabular}{|c|c|c|c|c|c|c|c|c|}
\hline Bacteria & \multicolumn{8}{|c|}{ Antibiotics } \\
\hline & Nit & Gen & $\mathrm{Nal}$ & Ofl & Aug & Tet & Amx & Cot \\
\hline $\begin{array}{l}\text { Klebsiella } \\
\text { pneumonia }\end{array}$ & 21 & 15.5 & 20.5 & 30 & 0 & 15.5 & 0 & 21 \\
\hline Pseudomonas sp. & 0 & 18.5 & 0 & 19 & 0 & 5 & 0 & 0 \\
\hline Escherichia coli & 30 & 29 & 0 & 37 & 0 & 0 & 0 & 15.5 \\
\hline Salmonella sp. & 18 & 17.5 & 20 & 27 & 0 & 14.5 & 0 & 19.5 \\
\hline
\end{tabular}

Table 6 Result of Phytochemical test

\begin{tabular}{|l|c|c|c|c|}
\hline Phytochemicals & $\begin{array}{l}\text { P.gunineense } \\
\text { (ethanol extract) }\end{array}$ & $\begin{array}{l}\text { T. tetraptera (aqueous } \\
\text { extract) }\end{array}$ & $\begin{array}{l}\text { P.gunineense } \\
\text { (aqueous extract) }\end{array}$ & $\begin{array}{l}\text { X. aethiopica } \\
\text { (ethanol extract) }\end{array}$ \\
\hline Alkaloids & - & - & - & - \\
\hline Flavonoids & + & + & + & - \\
\hline Glycosides & - & + & + & + \\
\hline Tannins & - & - & + & - \\
\hline Terpenoids & - & + & + & + \\
\hline Saponins & - & + & + & + \\
\hline
\end{tabular}

Phytochemical properties of plant extracts: The aqueous extract of Piper guineense contained terpenoids, tannins, saponins, flavonoids and glycosides except alkaloids while its ethanol extract contained only flavonoids and terpenoids (Table 6).

\section{DISCUSSION:}

The activity of plant extracts against bacteria has been studied for years but in a more intensified way during the last three decades. During this period numerous antimicrobial screening evaluations have been published based on the traditional use of Chinese, African and Asia plant-based drugs (Suffrendini et al.,2004). A large number of constitutive plant components have been reported to

have antimicrobial activity. Well known examples include phenols, unsaturated lactones, saponins, cyanogenic glycosides and glucosinolates (Adejumobi et al., 2008). The inhibitory effect of four plant extracts (spices) on some test organisms was investigated in vitro. The results obtained in this study revealed the antibacterial potential of these extracts especially the aqueous extract of Piper guineense. This is not surprising as the antimicrobial nature of many edible plant extracts such as cranberry, lime and lemon juices have been demonstrated (Mara et al., 2003). The influence of solvent for extraction on the inhibitory capacity of the extract on the test organism has been reported by Al-Bayati and Sulaiman (2008).
The antimicrobial properties of substances are desirable tools in the control of infections and in food spoilage (Aboaba, et al., 2005). The high level of sensitivity observed in the aqueous extracts towards the bacterial pathogens showed that the active components were soluble in water. This property is very desirable as these spices are used as condiments in food preparation. This supports the extensive use of these spices for treatment of ailments by traditional African medical practitioners. It is believed that the Piper guineense stimulates the production of hydrochloric acid in the stomach and promotes the health of the digestive tract.

Phytochemical screening showed the presence of terpenoids and the absence of alkaloids in all the spices. This is not surprising as alkaloids readily decompose with time. Aqueous extract of $P$. guineense indicated the presence of flavonoids while Tetrapleura tetraptera and $P$. guineense aqueous extracts contain glycosides. The glycosides detected are non-toxic but can get hydrolyzed to release phenolics which are toxic to microbial pathogens (Aboaba and Efuwape, 2001). Several phenolic compounds like tannins present in the cells of plants are potent inhibitors of many hydrolytic enzymes such as pectolytic macerating enzymes used by plant pathogens (Abd El Rahman et al., 2003, Osbourn, 1996). Plant based antimicrobials have enormous therapeutic potentials as they can serve the purpose with lesser side effects that are often associated with synthetic antimicrobials (Iwu et al., 1999). 
The active components of these extracts usually interfere with the growth and metabolism of microorganisms in a negative manner and are quantified by determining the minimum inhibitory concentration and the minimum bactericidal activity. These values are used as guide for the treatment of most infections (Aboaba, et al., 2005).

Comparing the sensitivity of the bacterial strains to both the plant extracts and to synthetic antibiotics, the result showed that the plant extracts can be used as an alternative to the antibiotics as the zones on inhibition shown were very comparable and the extracts have lesser side effects which are often associated with the use of antibiotics (Marchese and Shito, 2001; Poole, 2001). Also the issue of resistance to these extracts cannot arise as is found with antibiotics (Kareem et al., 2010). The results obtained support the fact that further work needs to be done to determine and identify, purify and quantify the antibacterial compound within these plants and also to determine their full spectrum of efficacy.

\section{CONCLUSION}

The aqueous extracts show promise and form a primary platform for further phytochemical and pharmacological studies for use as alternative therapy.

\section{REFERENCES}

Abd El Rahaman, H.F., Skaug, N. and Whyatt, A. (2003) Volatile compounds in crude Salvora persica extracts. Pharm. Bio. 41: 392-404.

Aboaba, O.O. and Efuwape, B.M. (2001). Antibacterial properties of some Nigerian spices. Bio. Res. Comm., 13:183-188.

Aboaba, 0.O., Smith, S.I. and Olude, F.O. (2005). Antibacterial effect of edible plant extracts on Escherichia coli 0157:H7. Pak. Journal of Nutr. 5(4): 325-327.

Adejumobi, J.A., Ogundiya, M.O., Kolapo, A.L. and Okunade, M.B. (2008). Phtochemical composition and in vitro antimicrobial activity of Anogeissus leiocarpus on some common oral pathogens. J. Med. Plants Res. 2(8):193-196.

Al-Bayati, F. A. and Sulaiman, K.D. (2008). In vitro antimicrobial activity of Salvadora persica L. extracts against some isolated oral pathogens in Iraq. Turk. Journal of Bio. 57-62

Harbone, D.B. (1998). Phytochemical methods, a guide to modern techniques of plant analysis. $3^{\text {rd }}$ ed. Springer, New Delhi.

Iwu, M.W., Duncan, A.R. and Okunji, C.O. (1999). New antimicrobials of plant origin. In: ed Perspectives on new crops and new uses. Alexandria, VA: ASHS Press. pp. 457-462.

Kareem, K.T., Kareem, S.O., Adeyemo, O. J. and Egberongbe, R.K. (2010) In vitro antimicrobial properties of Bridelia ferruginea on some clinical isolates. Agric. and Bio. Journal of North America. 1(3): 416-420.

Mara, C.L., Nogreira, A., Oyarzaba, O. and Gombass, E.D. (2003). Inactivation of E.coli 0157:H7, Listeria monocytogenes and Salmonella in cranberry, lemon and lime juice concentrates. Journal of Food Prot. 66: 1637-1641.

Marchese, A and Shito, G.C. (2001). Resistance pattern of lower respiratory tract pathogens in Europe. Inter. Journal of Antimic. Agents. 16: 25-29.

NCCLS (2006a) Performance Standard for Antimicrobial Disc Susceptibility Tests: Approved Standards, NCCLS Document, M2-T3. Villanova, P.A.

Ogundiya, M.O, Kolapo, A. L., Okunade, M.B and Adejumobi, J.A. (2009) Assessment of phytochemical composition and antimicrobial activity Terminalia glaucescens against some oral pathogens. Elect. Jour. of Envi, Agric. and Food Chem. 8(7): 466-471.

Osbourn,A.E. (1996) Preformed antimicrobial compounds and plant defence against fungal attack. The Plant Cell 8: 1821-1831.

Poole, K. (2001) Overcoming antimicrobial resistance by targeting resistance mechanisms. Journal of Pharm. and Pharm. 53: 283-284.

Rojas, R., Bustamante and Bauer, J. (2003). Antimicrobial activity of selected perphoian medicinal plants. Journal of Ethno. 88: 199-204.

Robbers, C., Speedie, M. and Tyler, V. (1996). Pharmacognosy and pharmacobiotechnology. Williams and Wilkins, Baltimore. 1-14

Suffrendini, I.B., Sarder, H.S., Goncalves, A.G. et al., (2004) Screening of antibacterial extracts from plants native to the Brazilian Amazon rainforest and Atlantic forest. Braz. J. Med. and Bio. Res.37: 379-384. 